\title{
MICROANATOMIC STUDY OF HUMAN PANCREATIC ISLETS IN ALCOHOLICS AND NON-ALCOHOLICS- A DESCRIPTIVE COMPARATIVE STUDY
}

\author{
Latha Sreedhar Lekshmi Sreedhar', Suja Robert Joseph Sarasammal2, Aswathy Maria Oommen ${ }^{3}$
}

${ }_{1}^{1}$ Associate Professor, Department of Anatomy, Government Medical College, Trivandrum, Kerala, India.

${ }^{2}$ Assistant Professor, Department of Anatomy, Government Medical College, Trivandrum, Kerala, India.

${ }^{3}$ Assistant Professor, Department of Anatomy, Government Medical College, Trivandrum, Kerala, India.

\section{ABSTRACT}

\section{BACKGROUND}

The islets of Langerhans are an important endocrine gland, which regulate the blood glucose level. The rise in blood glucose level results in diabetes mellitus, an age-old disease which affects all the systems of our body. Now-a-days, an increase in the incidence of diabetes mellitus and pancreatitis is noticed even in younger age groups and in alcoholics.

The aim of this study is to find out the microscopic changes in alcoholic islets in different age groups and correlate it with nonalcoholic islets.

\section{MATERIALS AND METHODS}

Thirty six autopsy specimens of alcoholic pancreas and forty specimens of non-alcoholic pancreas were collected from the mortuary of Govt. Medical College, Thiruvananthapuram, Kerala. Histological examination of the glands was done in histology laboratory of Dept. of Anatomy, Govt. Medical College, Thiruvananthapuram, Kerala. For statistical analysis, mean, SD and p-value were determined. Data analysis was performed using SPSS version 16.

\section{RESULTS}

According to the present study, alcoholism produces more changes in pancreatic islets. As age advances, the percentage of beta cells is very much reduced in alcoholic islets. The diameter of islets as well as the diameter of beta cells reduced as age advances in alcoholic islets, but in non-alcoholic islets the diameter of beta cells and islets gradually increase as age advances.

\section{CONCLUSION}

The intake of alcohol leads to degenerative changes in islets and also destruction of beta cells as age advances when compared with the non-alcoholic islets.

\section{KEY WORDS}

Pancreatic Islets, Alcoholism, Non-Alcoholism and Beta Cells.

HOW TO CITE THIS ARTICLE: Sreedhar LSL, Sarasammal SRJ, Oommen AM. Microanatomic study of human pancreatic islets in alcoholics and non-alcoholics- a descriptive comparative study. J. Evolution Med. Dent. Sci. 2018;7(49):5236-5240, DOI: $10.14260 /$ jemds/2018/1162

\section{BACKGROUND}

The alcoholism has a major effect on pancreatic islets cells and their insulin secretion. The microscopic study of pancreatic islets could prove to be useful for diabetologists. The endocrine structure of pancreas was extensively studied because of their clinical importance in many common conditions like diabetes mellitus, acute and chronic pancreatitis. With advancement in the medical field, the human pancreas is now being studied using various modalities like imaging, staining technique with advanced microscopy and enzyme immunoassay. This helps in expanding our knowledge of microscopic structure of pancreas and translating this information into research and clinical practice.

Ageing is one of the major factors affecting the progression of diabetes mellitus. Islets undergo natura degenerative changes, which steadily increase with age.

'Financial or Other Competing Interest': None.

Submission 06-07-2018, Peer Review 14-11-2018,

Acceptance 20-11-2018, Published 03-12-2018.

Corresponding Author:

Dr. Latha Sreedhar Lekshmi Sreedhar

Vettuvilayil, Karunya-197

Kochulloor, Trivandrum-695011, Kerala, India

E-mail: drlathals@gmail.com

DOI: $10.14260 /$ jemds/2018/1162
Alcoholism increases the ageing of islets and this might be one of the mechanisms for the prevalence of diabetes and pancreatitis in alcoholism.

In the present study, microscopic changes of islets and their cells were studied in alcoholic and non-alcoholic specimens and compared with each other. Researchers have observed that autoimmune diseases, blood cholesterol levels, $\mathrm{HbA}_{1} \mathrm{c}$ viruses and some chemicals also have a role in blood glucose level. Increased life expectancy rate also contributes to the increased incidence of diabetes mellitus.

Diabetes mellitus is an age-old problem, for which there is no complete cure. Recently, the incidence of diabetes mellitus has increased, and it may be due to increased consumption of alcohol even in younger generation.

\section{MATERIALS AND METHODS}

The autopsy specimens were collected from the mortuary of Govt. Medical College, Thiruvananthapuram, Kerala. The tissue samples were taken from the tail end of the pancreas, where islets are concentrated more. 36 specimens from the alcoholics and 40 from the non-alcoholics were collected.

\section{Inclusion Criteria}

Since autolysis of pancreas is rapid, samples were collected only from autopsies performed within 6 hours after death. 


\section{Exclusion Criteria}

1. Autopsies performed 6 hours after death.

2. Crush injuries of abdomen.

3. Foetuses with congenital anomalies of viscera.

The bits were taken from the gland and fixed in Bouin's fluid for 24 hours. After fixation the specimens were subjected to routine histological processing as per the standard procedure described by McManus and Mowry (1960). The paraffin tissue blocks were serially sectioned at a thickness of five microns using a rotary microtome. After incubating for one hour, the sections were stained with standard Haematoxylin and Eosin ( $\mathrm{H}$ and E) stain.

Microscopic evaluation of the islet cells with special stains like Masson's trichrome, chrome alum haematoxylin, PAS etc.

The mounted specimens were observed under low power and oil immersion objective of a binocular microscope. The sections were observed under oil immersion objective to study the characteristics of different types of cells and measurements were taken with a horizontal eyepiece micrometre called graticule, which is calibrated with a stage micrometre.

\section{Statistical Methods}

The data collected was entered into a Microsoft Excel Sheet. The analysis of data were done by using version 16 of Statistics Package for the Social Sciences (SPSS) software. Qualitative variables were expressed as proportion and quantitative variables were expressed as mean and standard deviation. Comparison of qualitative variation were analysis by chi-square test. Comparison of quantitative variables were analysis by unpaired t test. A p-value $<0.05$ was considered as statistically significant. Data analysis was performed using SPSS version 16 .

\section{RESULTS}

The sample collected for the present study were grouped acoording to the age groups (Table 1 ). In standard $\mathrm{H}$ and $\mathrm{E}$ staining, the islets appeared as more or less spherical masses of pale staining areas in which the cells were arranged as irregular anastomotic cords and surrounded by pancreatic acini (Fig. 6). The islets were separated from the acinar group by a thin capsule made up of reticular fibres, clearly distinguished by Mallory trichrome stain (Fig. 5).

According to the present study in alcoholic specimens, the percentage of beta cells very much increased in age group of 21-30 yrs. (Fig. 2) when correlated with non-alcoholic specimens of similar age group (Fig. 1, Table-2). The percentage slightly decreased in age group $31-40$ yrs. (Fig. 3 , 4). When compared with non-alcoholic islets. The percentage of beta cells very much decreased in age group 41 - 50 yrs. in alcoholics when correlated with non-alcoholic islets. Above 50 yrs., the percentage of beta cells again decreased slightly when compared with non-alcoholic islets (Fig. 8, 9). (The mean, SD and p values are given in Table-2).

In alcoholic islets the average diameter of beta cells slightly increased from 21 - 40 yrs. and after age 40 the diameter of beta cells decreased. But in non-alcoholic islets, there is gradual increase in the diameter of beta cells from 21 yrs. to 80 yrs. (Fig. 10, 12) (Table-3).

The average diameter islets in alcoholics increased much in age group 21 - 30 yrs. when compared with non-alcoholic islets (Fig. 2 and 1). After 30 yrs., the diameter of islets decreased to a very low level. After 40 yrs., the diameter is about 55 to 60 percentage of non-alcoholic islets. But in nonalcoholic islets, the diameter gradually increased from 21 yrs. to 80 yrs. (Fig. 10, 11) (Table-4).

The changes were predominant as age advances in alcoholic islets when correlated with non-alcoholic islets of similar age group (Fig. 10, 11). In a 68-year-old alcoholic, the number of beta cells decreased, and the alpha cells increased (Fig. 12). In an 80-year-old alcoholic, the diameter of islets decreased, but their number increased (Fig. 11). Whereas in 80-year-old non-alcoholic, large islets with a smaller number of beta cells was observed (Fig. 10).

In a 48-year-old chronic alcoholic patient, the changes were segmental, in one segment hyperplasia of islets was observed (Fig. 6) and in another segment, a large islet with increased number of beta cells appeared (Fig. 7) when compared with non-alcoholic of similar age group (Fig. 5).

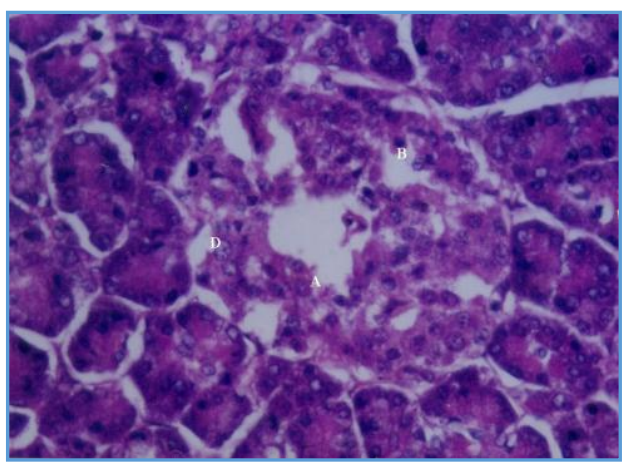

Figure 1. Age 25 yrs. Non-alcoholic, Chrome Alum Haematoxylin-Phloxine Stain (X400) A- Alpha cells, B-Beta cells, D-Delta cells

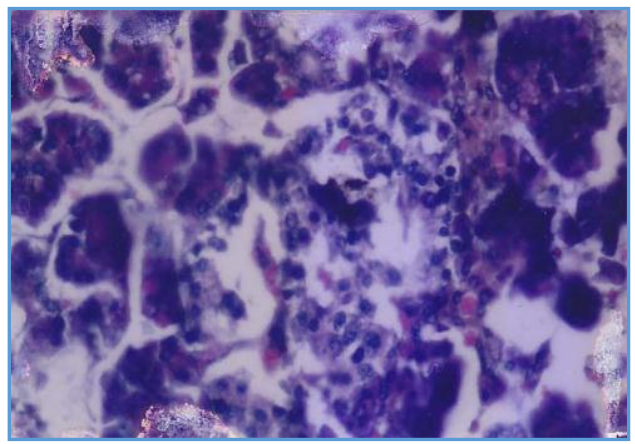

Figure 2. Age 25 yrs., Alcoholic, Chrome Alum Haematoxylin Stain (X400) Alpha cells, B-Beta cells

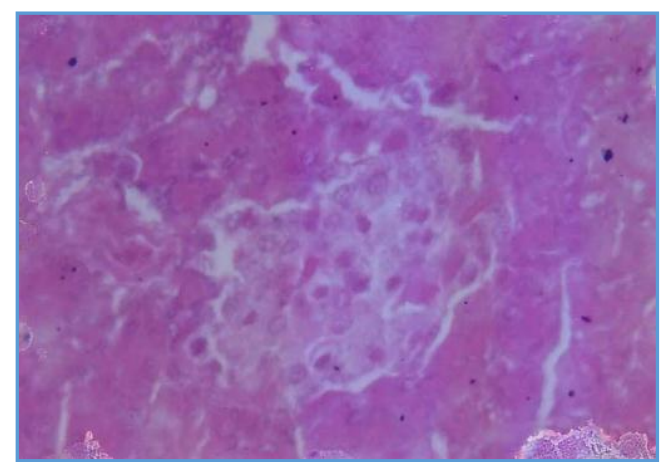

Figure 3. Age 38 yrs. Non-Alcoholic, Azocarmine Stain (X400) Alpha cells, B-Beta cells 


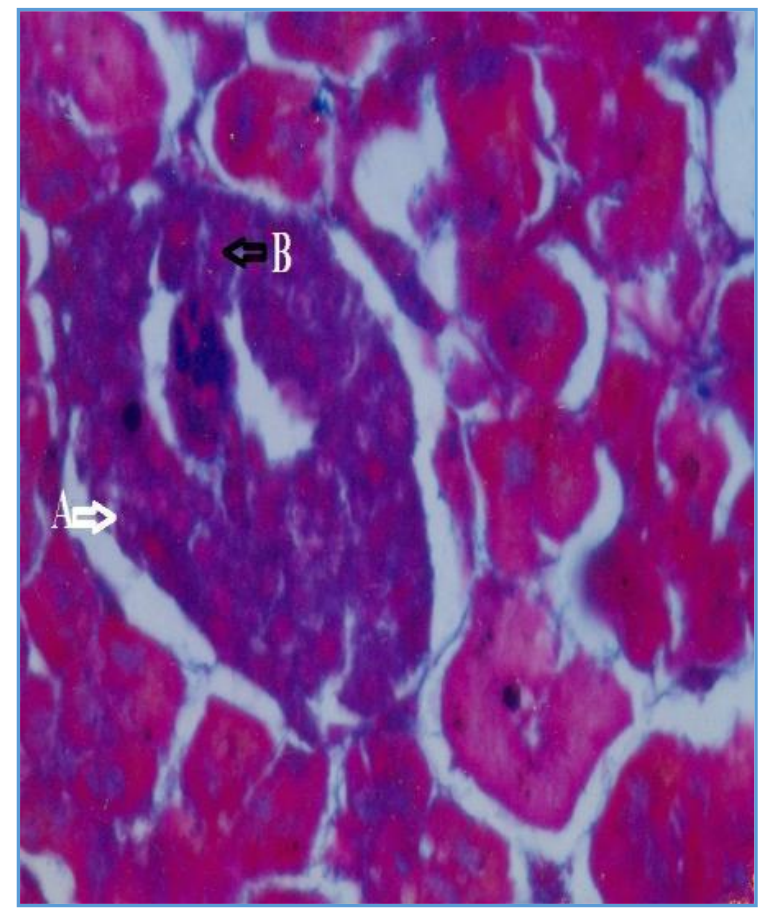

Figure 4. Age 38 yrs. Alcoholic, Mallory Heidenhain's Azocarmine Stain (X400) Alpha cells, B-Beta cells

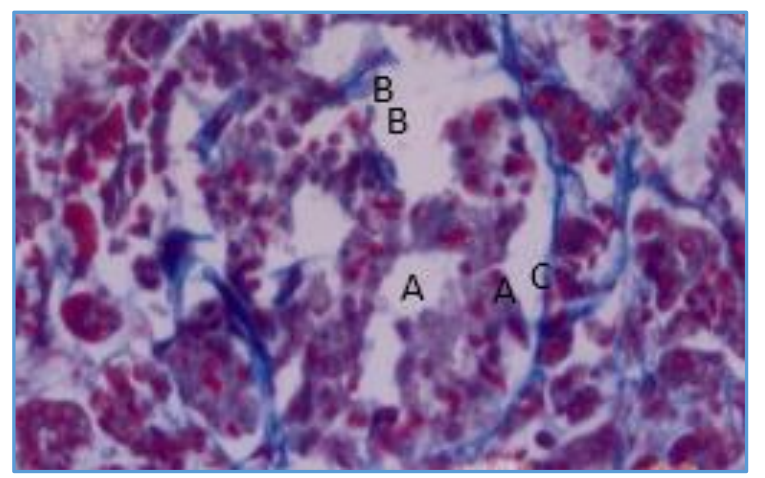

Figure 5. Age 47 yrs., Non-Alcoholic, Mallory Trichrome Stain (X400) Alpha, B-Beta cells, C-Capsule

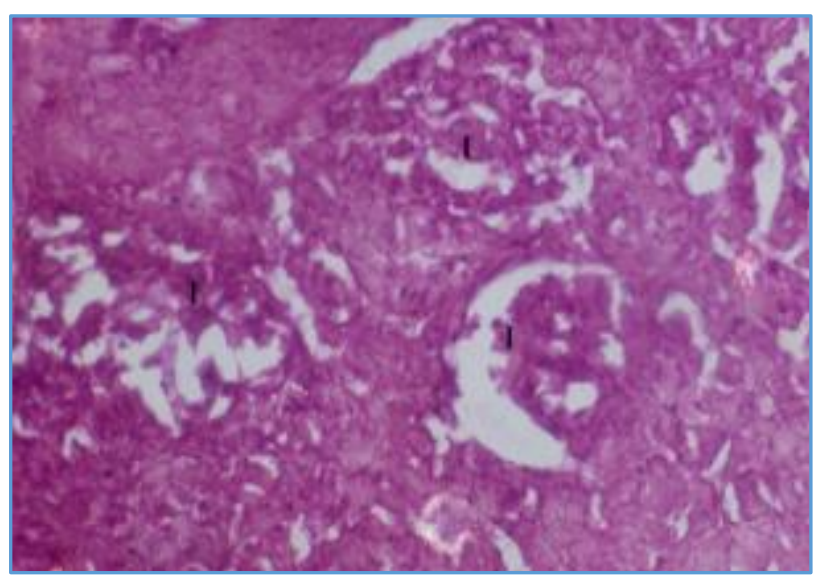

Figure 6. Age 47 yrs., Chronic Alcoholic, Mallory Heidenhain's Azocarmine Stain Hyperplasia of Islets (I) $(X 100)$

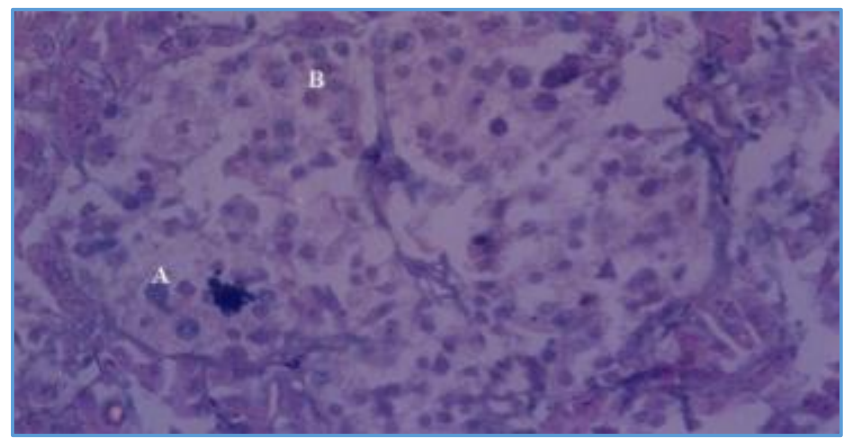

Figure 7. Age 47 yrs., Chronic Alcoholic, Haematoxylin Phloxine Stain (X400) Confluence of Islets. A- Alpha cells, $B$-Beta cells

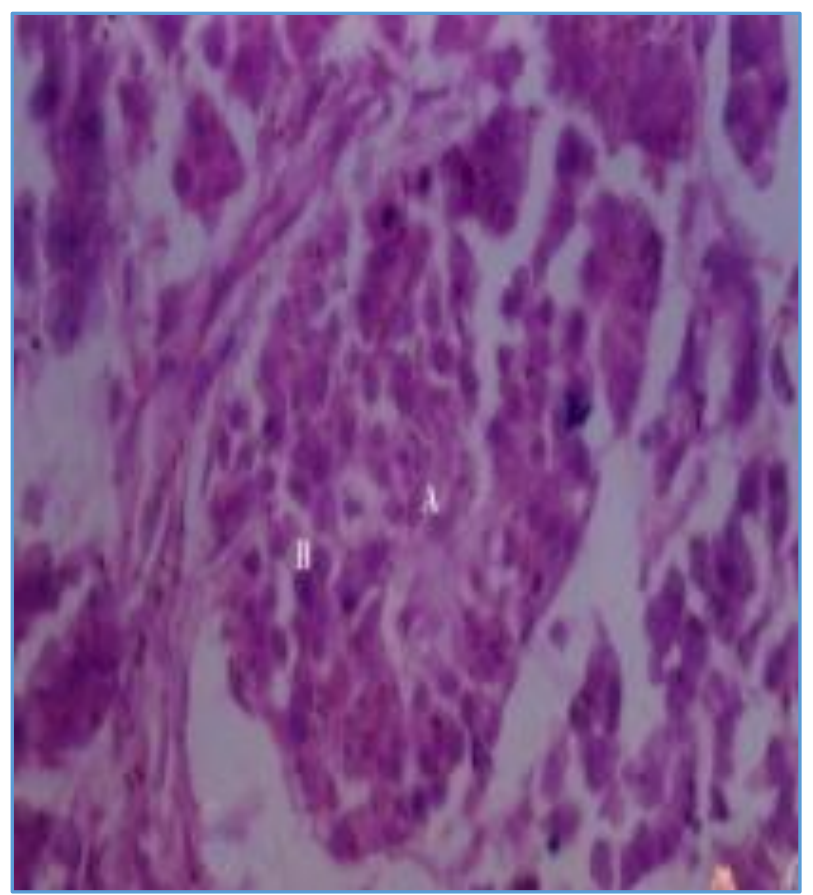

Figure 8. Age 55 yrs., Non-Alcoholic, Haematoxylin Phloxine Stain (X400) Alpha cells, B-Beta cells

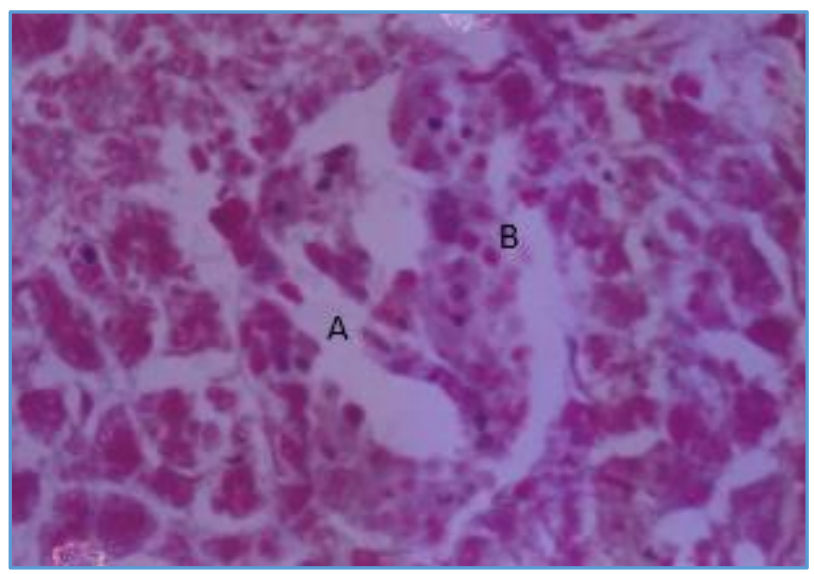

Figure 9. Age 55 yrs., Alcoholic, Azocarmine Stain (X400) A- Alpha cells, B-Beta cells 


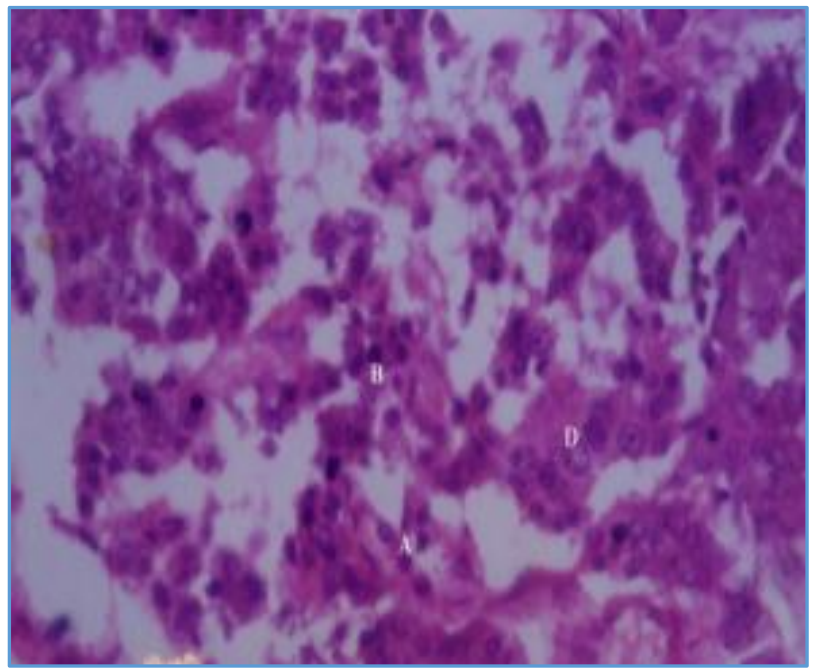

Figure 10. Age 80, Non-Alcoholic, Azocarmine Stain, a Large Islet with Less Number of Cells (X400)

A- Alpha cells, B-Beta cells, D-Delta cells

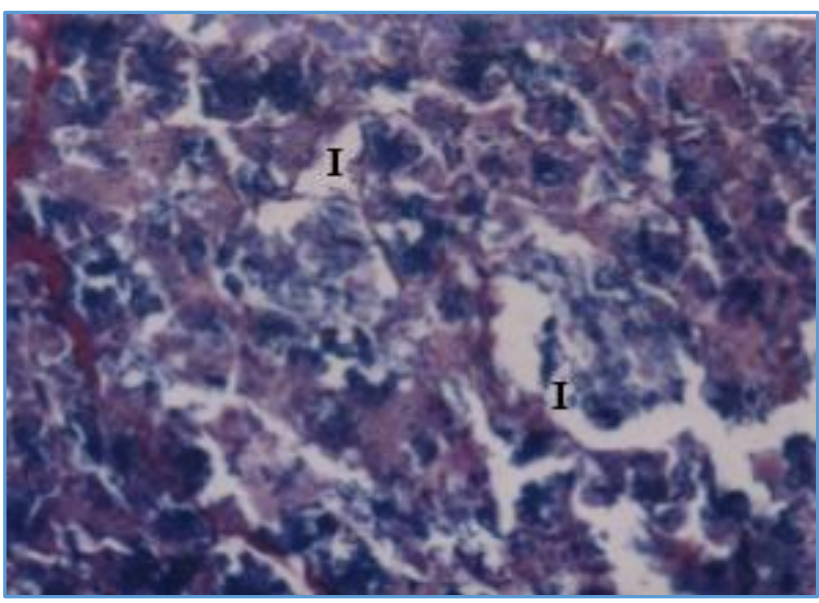

Figure 11. Age 80 yrs. old, Alcoholic, Multiple Islets (I) With Less Number of Cells Haematoxylin Phloxine Stain (X100)

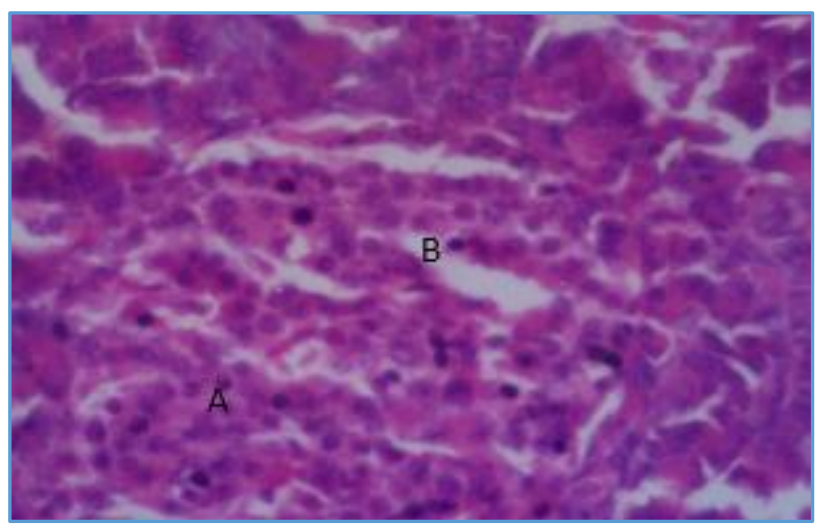

Figure 12. Age 68 yrs., Alcoholic with Less Number of Beta Cells (B), A-Alpha cells more, Azocarmine Stain (X400)

\begin{tabular}{|c|c|c|c|c|c|c|c|c|c|}
\hline & $\begin{array}{c}\text { Non- } \\
\text { Alcoholic }\end{array}$ & \multicolumn{2}{|c|}{ Alcoholic } & \multicolumn{2}{|c|}{ Total } & \multirow{2}{*}{$\chi^{2}$} & df & p \\
\cline { 1 - 5 } $\begin{array}{c}\text { Age } \\
\text { (years) }\end{array}$ & $\mathrm{N}$ & $\%$ & $\mathrm{~N}$ & $\%$ & $\mathrm{~N}$ & $\%$ & & & \\
\hline $21-30$ & 5 & 12.5 & 6 & 16.7 & 11 & 14.5 & 2.128 & 3 & .546 \\
\hline $31-40$ & 7 & 17.5 & 8 & 22.2 & 15 & 19.7 & & & \\
\hline $41-50$ & 11 & 27.5 & 12 & 33.3 & 23 & 30.3 & & & \\
\hline$>50$ & 17 & 42.5 & 10 & 27.8 & 27 & 35.5 & & & \\
\hline Total & 40 & 100.0 & 36 & 100.0 & 76 & 100.0 & & & \\
\hline \multicolumn{8}{|c|}{ Table I. No. of Specimen } \\
\hline
\end{tabular}

\begin{tabular}{|c|c|c|c|c|c|c|c|}
\hline \multirow{3}{*}{$\begin{array}{c}\text { Age } \\
\text { (Years) }\end{array}$} & \multirow{3}{*}{$\mathbf{N}$} & \multicolumn{5}{|c|}{$\% \beta$ Cells in One Islet } & \multirow{3}{*}{$\mathbf{p}$} \\
\hline & & \multicolumn{2}{|c|}{ Non-Alcoholic } & \multirow{2}{*}{$\mathbf{N}$} & \multicolumn{2}{|c|}{ Alcoholic } & \\
\hline & & Mean & SD & & Mean & SD & \\
\hline $21-30$ & 5 & 79.14 & 2.545 & 6 & 85.80 & 5.371 & 0.008 \\
\hline $31-40$ & 7 & 80.80 & 2.700 & 8 & 78.14 & 17.584 & 0.642 \\
\hline $41-50$ & 11 & 70.25 & 4.235 & 12 & 55.60 & 15.291 & 0.001 \\
\hline$>50$ & 17 & 58.43 & 4.088 & 10 & 53.65 & 3.823 & 0.001 \\
\hline
\end{tabular}

\begin{tabular}{|c|c|c|c|c|c|c|c|}
\hline \multirow{3}{*}{$\begin{array}{c}\text { Age } \\
\text { (Years) }\end{array}$} & \multirow{3}{*}{$\mathbf{N}$} & \multicolumn{5}{|c|}{ Average Diameter of $\beta$-cells $(\mu \mathrm{m})$} & \multirow{3}{*}{$\mathbf{p}$} \\
\hline & & \multicolumn{2}{|c|}{ Non-Alcoholic } & \multirow[b]{2}{*}{$\mathbf{N}$} & \multicolumn{2}{|c|}{ Alcoholic } & \\
\hline & & Mean & SD & & Mean & SD & \\
\hline $21-30$ & 5 & 4.79 & 0.29 & 6 & 5.15 & 0.72 & 0.227 \\
\hline $31-40$ & 7 & 5.81 & 0.64 & 8 & 5.59 & 0.63 & 0.415 \\
\hline $41-50$ & 11 & 5.76 & 0.26 & 12 & 5.45 & 0.40 & 0.016 \\
\hline$>50$ & 17 & 6.17 & 0.29 & 10 & 5.01 & 0.46 & 0.000 \\
\hline \multicolumn{8}{|c|}{ Table III. Average diameter of $\beta$-Cells ( $\mu \mathrm{m})$} \\
\hline
\end{tabular}

\begin{tabular}{|c|c|c|c|c|c|c|c|}
\hline \multirow{3}{*}{$\begin{array}{c}\text { Age } \\
\text { (Years) }\end{array}$} & \multirow{3}{*}{$\mathbf{N}$} & \multicolumn{5}{|c|}{ Average Diameter of Islet $(\mu \mathrm{m})$} & \multirow{3}{*}{$\mathbf{p}$} \\
\hline & & \multicolumn{2}{|c|}{ Non-Alcoholic } & \multirow[b]{2}{*}{$\mathbf{N}$} & \multicolumn{2}{|c|}{ Alcoholic } & \\
\hline & & Mean & SD & & Mean & SD & \\
\hline $21-30$ & 5 & 140.6 & 2.8 & 6 & 157.6 & 10.1 & 0.001 \\
\hline $31-40$ & 7 & 166.4 & 3.3 & 8 & 138.4 & 34.7 & 0.019 \\
\hline $41-50$ & 11 & 169.8 & 3.2 & 12 & 105.9 & 6.3 & 0.000 \\
\hline$>50$ & 17 & 177.8 & 6.6 & 10 & 100.6 & 3.1 & 0.000 \\
\hline \multicolumn{8}{|c|}{ able IV. Average diameter of Islet $(\mu \mathrm{m})$} \\
\hline
\end{tabular}

\section{DISCUSSION}

The alcoholic changes in the microanatomy of human pancreatic islets has attracted the attention of many researchers due to the increased incidence of diabetes mellitus in alcoholics. The present work provides an opportunity to understand the microanatomy of normal human pancreatic islets as well as in alcoholic patients and correlate with each other.

The occurrence of beta cells more in the age group of 21$30 \mathrm{yrs}$. in alcoholics when compared to that of non-alcoholics. In younger age group, the alcoholism increased the blood glucose level by increasing the appetite as well as by stimulating the alpha cells in islets. ${ }^{1}$ The beta cells also multiplied to compensate the increased level of blood glucose. ${ }^{2}$ In the age group of 31 - 40 yrs., the diameter, the number of islets and the number of beta cells increased as studied by Morgan CR and A Lazarou ${ }^{3,4}$ in non-alcoholics. But in alcoholics the diameter of beta cells decreased and the number of beta cells and diameter of islets increased. Experiments done by Sarles $\mathrm{H}$, in rats after alcohol administration more than ten years showed similar findings. ${ }^{5}$ 
In a 48-year-old chronic alcoholic patient, the findings were segmental. In one segment there were hyperplasia of islets and in another segment a large islet group with more number of beta cells were seen. ${ }^{6}$ This increased number of beta cells may be to counteract the reduced secretion of insulin. ${ }^{7}$ In chronic alcoholics, there were neoproliferation of beta cells. ${ }^{8}$ According to Laidlow, this neoproliferation is thought to be the morphologic changes underlying certain forms of hyperglycaemias seen in alcoholism. ${ }^{9}$

Above 50 years in alcoholics, the number of beta cells very much decreased and the alpha cells increased. In an 80 years old chronic alcoholic patient, the beta cells were decreased and the size of islets also decreased. Alcoholism may lead to decreased response of insulin to glucose as a result, the islets multiplied in order to secrete more insulin. ${ }^{10}$ As age advances, in alcoholics the number of islets as well as its diameter decreased.11 This is because of the degenerative changes occurred in islets by the effect of alcohol. ${ }^{12}$ The alcoholic changes in pancreatic islets may not be uniform in persons because certain chemicals like alloxan, genetic factors, composition of diet and autoimmune diseases could influence the islets. ${ }^{13}$

Alcoholic pancreatitis is not a strong risk factor for pancreatic cancer like genetically determined chronic pancreatitis. Pancreatitis could be triggered during pregnancy due to CYP 24 AI mutation. ${ }^{14}$ Association between IgE mediated allergic conditions and diabetes mellitus was also detected. Recently, Marabitat and Islamms reported the expression of transient receptor potential channels in the purified human pancreatic beta cells.

\section{CONCLUSION}

1. In alcoholics, as age advances, more degenerative changes occurred in islets when correlated with nonalcoholic islets.

2. As age advances, the destruction of beta cells was more in alcoholic islets when compared with non-alcoholic islets.

3. Because of the degenerative changes in islets and destruction of more beta cells, type-II diabetes mellitus and pancreatitis appeared earlier in alcoholics.

4. In chronic alcoholics on insulin treatment, pancreas showed hyperplasia of islets and increased number of beta cells.

So, the present study compares the microanatomy of pancreatic islets in alcoholics and non-alcoholics. Over consumption of alcohol produces increased level of glucose in blood by gluconeogenesis; to counteract these islets multiplied and the size and number of beta cells also increased leading to development of alcoholic diabetes mellitus. As age advanced, degenerative changes occurred in the islets, especially in beta cells. This is only a preliminary study, as this is done on autopsy specimens.

\section{ACKNOWLEDGEMENT}

I thankfully acknowledge the guidance and valuable suggestions of Dr. Aleyamma Fenn, TKMS Professor and Head, Department of Anatomy, Govt. Medical College, Palakkad and Dr. V M Kurshid, MS, Professor of Anatomy, Sree Gokulam Medical College and Research Centre, Trivandrum and Dr. Renuka K, Professor and HOD, Govt. Medical College, Trivandrum.

\section{REFERENCES}

[1] Berry DC, Williams W, Hall EG, et al. Imbedding interdisciplinary diabetes group visits into a community based medical setting. Diabetes Educ 2016;42(1):96-107.

[2] Bayley JM. Staining methods for the islets of Langerhans. J Pathol 1973;44(1):272-6.

[3] Bencosme SA. The histogenesis and cytology of the pancreatic islets in the rabbit. Am J Anat 1995;96(1):103-51.

[4] Morgan CR, Carpenter AM, Lazarow A. Effect of insulin antibodies on pancreatic islet insulin and beta cell granule content. Anat Rec 1965;153(1):49-54.

[5] Sarles H. An international survey on nutrition and pancreatitis. Digestion 1973;9(5):389-403.

[6] Gomori G. Observations with differential stains on human islets of Langerhans. Am J Pathol 1941;17(3):395-406.

[7] Hard WL. The origin and differentiation of the alpha and beta cells in the pancreatic islets of the rat. Am J Anat 1944;75(3):369-403.

[8] Bloom W. A new type of granular cells in islets of Langerhans of man. Anatomical Record 1931;49(4):363-71.

[9] Laidlaw GF. Nesidioblastoma, the islet tumor of the pancreas. Am J Pathol 1938;14(2):125-34.

[10] Toreson WE. Glycogen infiltration (so-called hydropic degeneration) in the pancreas in human and experimental diabetes mellitus. Am J Pathol 1951;27(2):327-47.

[11] Woerner CA. Studies of the islands of Langerhans after continuous intravenous injection of dextrose. Anat Record 1938;71(1):33-57.

[12] Hellman B. Actual distribution of the number and volume of the islets of Langerhans in different size classes in non-diabetic humans of varying ages. Nature 1959;184(Suppl 19):1498-9.

[13] Pearc RM. The development of the islets of Langerhans in the human embryo. Am J Anat 1903;2(4):445-55.

[14] Vanralte DA, Bunck M. Ultra structural, study on human pancreatic islets. Euro Journal Endocrinology 2016;1:77-113. 